\title{
Inclusion of in-situ Green Manuring as One of the Important INM Practice to Improve the Growth and Economics of Potato (Solanum tuberosum L.)
}

\author{
D.S. Prabhudeva ${ }^{1^{*}}$, R. Jayaramaiah ${ }^{2}$ and M.N. Thimmegowda ${ }^{3}$ \\ ${ }^{1}$ Department of Agronomy, College of Agriculture, UAS, GKVK, Bangalore-560065 \\ (Karnataka), India \\ ${ }^{2}$ Department of Agronomy, College of Agriculture, Hassan-573225 (Karnataka), India \\ ${ }^{3}$ AICRP on Dryland Agriculture, UAS, GKVK, Bangalore-560065 (Karnataka), India \\ *Corresponding author
}

\begin{tabular}{|l|}
\hline Ke y w o r d s \\
INM, In-situ green \\
manuring, RDF, B: \\
C ratio
\end{tabular}

\section{Introduction}

Sustainable crop production depends upon the rational use of chemical fertilizers and pesticides along with organic manures for better soil health. Owing to the constant production of crops from the soil, the latter is being depleted gradually of its nitrogenous and other nutrients. An ordinary crop takes and $50 \%$ compost.

\section{A B S T R A C T}

A field experiment was done to assess the influence of INM practices with in-situ green manuring on growth and yield of potato at College of Agriculture, Hassan, UAS, Bangalore during Kharif 2013. The experiment was laid out in a factorial Randomized Complete Block Design (FRCBD) with three replications and twelve treatment combinations including 2 fertilizer levels (75 and 100\% RDF), 3 compost levels (0, 12.5 and $25 \mathrm{t} \mathrm{ha}^{-1}$ compost) and in-situ green manuring with sunhemp and cowpea. The investigation revealed that among treatment combinations, $100 \% \mathrm{RDF}+25 \mathrm{t} \mathrm{ha}^{-1}$ compost + in-situ green manuring with cowpea recorded significantly higher plant height $(73.1 \mathrm{~cm})$, number of leaves $\left(83.3\right.$ plant $\left.^{-1}\right)$, leaf area $\left(7576 \mathrm{~cm}^{2}\right.$ plant $\left.^{-1}\right)$, leaf area index $(6.3)$, leaf area duration (101.3 days) and total dry matter production $\left(71.5 \mathrm{~g} \mathrm{plant}^{-1}\right)$. The higher net returns and $\mathrm{B}: \mathrm{C}$ ratio (Rs. 1,01,550 $\mathrm{ha}^{-1}$ and 2.58 , respectively) was recorded in the treatment with $75 \% \mathrm{RDF}+12.5 \mathrm{t} \mathrm{ha}^{-1}$ compost + in-situ green manuring with cowpea $\left(\mathrm{T}_{4}\right)$ followed by $100 \% \mathrm{RDF}+25 \mathrm{t} \mathrm{ha}^{-1}$ compost + in-situ green manuring with cowpea $\left(\mathrm{T}_{12}\right)$. Application $75 \%$ recommended dose of NPK with $12.5 \mathrm{t} \mathrm{ha}^{-1}$ compost and in-situ green manuring with cowpea recorded less reduction in the tuber yield with high net returns and $\mathrm{B}: \mathrm{C}$ ratio and it is economically feasible for the potato cultivation by saving $25 \%$ fertilizer 
chemical fertilizers tends to favour economically those farmers with large hectarage. These considerations have led to a renewed interest in the organic manures such as FYM, compost and green manures.

Green manuring - a practice of ancient origin, is defined as the use of undecomposed green plant material, grown in situ or cut and brought in for incorporation to improve soil productivity. Green manuring is, thus, a very useful soil-improving practice for building up soil fertility. First, it increases the soil fertility by the direct addition of $\mathrm{N}$ to the soil. Second, it improves the soil texture by the addition of humus or organic matter, which is essential for making the soil more productive. The addition of organic matter improves both heavy and sandy soils, as it has a binding effect on the loose particles of the sandy soils and makes the hard and heavy soils porous. Thus, it also increases the water-holding capacity of the soil. Besides, the conditions for increasing the number of useful bacteria in the soil are also improved (Meelu et al., 2007).

Potato is an arable crop prefers loose and friable soil for its normal growth and development. Economic part (tubers) of the crop developing in the soil, maintenance of arable / friable soil condition is essential even up to maturity of the crop. Application of organic manures in huge quantities is essential to ensure optimal soil physical condition. In the present scenario of reduced animal population, deforestation etc., availability of organic manure has reduced considerably. In view of this as an alternative inclusion of green manures either in rotation or intercropping are possibly need to explore.

Green manures exhibited significant influence on potato by reduction of verticillium wilt, increased quality of potatoes, provided fertilizer replacement values of 50 to 120 pounds of nitrogen per acre, supressed nematodes, reduced early die, reduced weeds and needs of some herbicides (Brian, 2001)

Potato cultivation is one of the major sources of income to the local farmers in the study area. Nutrient management in potato production in this area is highly intensive, relying heavily on chemical fertilizers and apart from this, the area receives pre-monsoon showers. By taking advantage of pre-monsoon showers, the in-situ green manuring could be possible and successful. With the above background, the present investigation was carried out to assess the Inclusion of in-situ green manuring as one of the important INM practice to improve the growth and economics of potato.

\section{Materials and Methods}

The experiment was conducted at the college of agriculture, Hassan, UAS, Bangalore, Karnataka in Kharif 2013. The soil was neutral in reaction $(\mathrm{pH} 7.08)$ and organic carbon content $(0.48 \%)$ was low. The soil test results of the experimental site reveal that soil is medium in nitrogen (330.5 $\mathrm{kg} \mathrm{h}{ }^{-1}$ ), phosphorus (53.3 kg ha $\mathrm{kg}^{-1}$ and potassium $\left(215.0 \mathrm{~kg} \mathrm{ha}^{-1}\right)$. During the cropping season (June 2013 - September 2013), a total of 459.5 $\mathrm{mm}$ rainfall was received. The field experiment was laid out in a factorial Randomized Complete Block Design (RCBD) with three replications. There were 12 treatment combinations comprising of 2 fertilizer levels (75 and 100\% RDF), 3 compost levels $\left(0,12.5\right.$ and $25 \mathrm{t} \mathrm{ha}^{-1}$ compost) and in-situ green manuring with sunhemp and cowpea were included in this study. The treatment combinations were $\mathrm{T}_{1}: 75 \%$ recommended NPK + control + in-situ green manuring with sunhemp, $\mathrm{T}_{2}: 75 \%$ recommended NPK + control + in-situ green manuring with cowpea, $\mathrm{T}_{3}: 75 \%$ recommended $\mathrm{NPK}+12.5 \mathrm{t} \mathrm{ha}^{-1}$ compost + in-situ green manuring with sunhemp, $\mathrm{T}_{4}: 75 \%$ 
recommended NPK $+12.5 \mathrm{tha}^{-1}$ compost $+i n$ situ green manuring with cowpea, $\mathrm{T}_{5}: 75 \%$ recommended NPK $+25 \mathrm{tha}^{-1}$ compost + insitu green manuring with sunhemp, $\mathrm{T}_{6}: 75 \%$ recommended NPK $+25 \mathrm{t} \mathrm{ha}^{-1}$ compost $+i n$ situ green manuring with cowpea, $\mathrm{T}_{7}: 100 \%$ recommended NPK + control + in-situ green manuring with sunhemp, $\mathrm{T}_{8}: 100 \%$ recommended NPK + control + in-situ green manuring with cowpea, $\mathrm{T}_{9}: 100 \%$ recommended NPK $+12.5 \mathrm{tha}^{-1}$ compost $+i n$ situ green manuring with sunhemp, $\mathrm{T}_{10}: 100 \%$ recommended NPK $+12.5 \mathrm{t} \mathrm{ha}^{-1}$ compost + in-situ green manuring with cowpea, $\mathrm{T}_{11}: 100 \%$ recommended NPK $+25 \mathrm{t} \mathrm{ha}^{-1}$ compost + in-situ green manuring with sunhemp, $\mathrm{T}_{12}: 100 \%$ recommended NPK $+25 \mathrm{t}$ $\mathrm{ha}^{-1}$ compost + in-situ green manuring with cowpea.

After the harvest of fodder maize grown during Rabi season of 2012-2013 the land was prepared by using disc plough followed by passing cultivator to break the clods and to collect weeds and stubbles. Finally the land was levelled using a bullock drawn leveller. The plot size was $3.6 \mathrm{~m} \times 3.2 \mathrm{~m}\left(11.52 \mathrm{~m}^{2}\right)$. In-situ green manure crops (cowpea and sunhemp) were sown in their respective plots and incorporated at 45 DAS. On an average cowpea and sunhemp added 22.5 and $13.7 \mathrm{t}$ ha $^{-1}$ biomass, respectively (Table 1). Calculated quantities of compost were incorporated into the soil in each plot 15 days before planting of potato for proper decomposition according to the treatments.

Seed tubers of KufriJyothi weighing approximately 30-40 grams were dipped in a solution of Dithane M-45 (2 $\mathrm{g}$ in one litre of water) for 20 minutes and dried in shade before planting to prevent the decay of seed tubers. After bringing the soil to fine tilth, furrows at $60 \mathrm{~cm}$ apart were formed and calculated quantities of recommended dose of 125:100:125 kg N, $\mathrm{P}_{2} \mathrm{O}_{5}$ and $\mathrm{K}_{2} \mathrm{O}$ ha $^{-1}$ were applied in the form of urea, diammonium phosphate and muriate of potash, respectively as per the treatments to the each plot and mixed well into the soil. The tubers were planted half way the ridge at a distance of 20 $\mathrm{cm}$. Fifty per cent of the recommended nitrogen was applied at the time of planting and remaining fifty per cent was applied four weeks after planting as top dressing. Common irrigation was given to all the treatments during the dry spell using portable sprinkler. Totally 4 irrigations were scheduled during the cropping period.

Five plants were randomly selected in net plot and labelled. Observations on growth parameters were recorded using these plants. The cost of cultivation was computed by considering the present prices of inputs prevailed during their use for different treatments. Similarly, the ruling market price for potato was considered for calculating gross return. The cost of cultivation was deducted from gross returns to arrive at net profit per hectare. Benefit cost ratio was worked out by dividing the gross returns to the total cost of cultivation. The data pertaining to the experiment were subjected to statistical analysis suggested by Gomez and Gomez (1984) and results were compared.

\section{Results and Discussion}

\section{Meteorological condition during cropping period}

During the cropping season (June 2013 September 2013), a total of $459.5 \mathrm{~mm}$ rainfall was received (Table 2). The average maximum air temperature of $30.1{ }^{\circ} \mathrm{C}$ in the month of September 2013 and minimum temperature of $18.7{ }^{\circ} \mathrm{C}$ during the month of June and September 2013 was recorded. The mean monthly relative humidity ranged from 80 per cent in May - June to 85 per cent in July - August. 
The fluctuations in weather conditions truly reflected on expected yield. During kharif 2013, the crop experienced favourable weather condition during its growth. A total rainfall of $459.5 \mathrm{~mm}$ was received during the crop growth period, which was slightly less than the normal. Mean monthly maximum temperature and mean monthly minimum temperature were higher than their normal values. The actual maximum relative humidity was higher than the normal during the crop growth period.

\section{Growth parameters}

The growth components of potato significantly increased with increasing rates of RDF (Table 3). Among the fertilizer levels, $100 \%$ RDF recorded significantly taller plants $(68.1 \mathrm{~cm})$, higher number of leaves $(70.7$ plant $\left.{ }^{-1}\right)$, leaf area $\left(6159 \mathrm{~cm}^{2}\right.$ plant $\left.^{-1}\right)$, leaf area index (5.1), leaf area duration (84.3 days) and total dry matter production (54.2 $\left.\mathrm{g} \mathrm{plant}^{-1}\right)$ except number of shoots plant ${ }^{-1}$ compare to $75 \%$ RDF. Our results are in agreement with those of Riley (2000), Van delden (2001) and Mondal et al., (2005) who reported that growth and growth components increased with higher fertilizer rate.

Application of higher level of compost at $25 \mathrm{t}$ $\mathrm{ha}^{-1}$ recorded significantly higher plant height $(70.6 \mathrm{~cm})$, number of shoots plant ${ }^{-1}$ (3.8), number of leaves (76.2 plant $\left.^{-1}\right)$, leaf area $\left(6945 \mathrm{~cm}^{2}\right.$ plant $\left.{ }^{-1}\right)$, leaf area index (5.7), leaf area duration (93.9 days) and total dry matter production (63.6 $\mathrm{g} \mathrm{plant}^{-1}$ ) compare to no compost application. Application of compost improved the growth parameters probably due to improved soil physical condition and supply of macro and micro nutrients. These results are in line with the findings of Ashwini Kumar Sharma and Sarjeet Singh (2000) and Krishnamurthy et al., (2002).

Table.1 Biomass added and nutrients content of green maures and compost

\begin{tabular}{|c|c|c|c|}
\hline \multirow{2}{*}{ Particulars } & \multicolumn{2}{|c|}{ Green manures } & \multirow{2}{*}{ Compost } \\
\hline & cowpea & sunhemp & \\
\hline $\mathrm{N}(\%)$ & 0.89 & 0.71 & 0.58 \\
\hline $\mathrm{P}_{2} \mathrm{O}_{5}(\%)$ & 0.15 & 0.12 & 0.43 \\
\hline $\mathrm{K}_{2} \mathrm{O}(\%)$ & 0.58 & 0.51 & 0.97 \\
\hline Biomass added $\left(\mathbf{t} \mathrm{ha}^{-1}\right)$ & 22.5 & 13.7 & - \\
\hline
\end{tabular}

Table.2 Meteorological data of experimental site for the cropping period at College of Agriculture, Hassan

\begin{tabular}{|c|c|c|c|c|}
\hline Month & Rainfall $(\mathbf{m m})$ & $\begin{array}{c}\text { Minimum } \\
\text { temperature }\left({ }^{\circ} \mathbf{C}\right)\end{array}$ & $\begin{array}{c}\text { Maximum } \\
\text { temperature }\left({ }^{\circ} \mathbf{C}\right)\end{array}$ & $\begin{array}{c}\text { Relative } \\
\text { humidity }(\%)\end{array}$ \\
\hline June & 162.0 & 18.7 & 29.4 & 81.5 \\
\hline July & 61.5 & 21.3 & 28.1 & 84.7 \\
\hline August & 122.0 & 23.1 & 29.0 & 83.8 \\
\hline September & 114.0 & 18.7 & 30.1 & 82.7 \\
\hline Total & 459.5 & & & \\
\hline
\end{tabular}


Int.J.Curr.Microbiol.App.Sci (2018) 7(11): 692-698

Table.3 Growth parameters as influenced by INM practices with in-situ Green manuring in potato

\begin{tabular}{|c|c|c|c|c|c|c|c|}
\hline Treatments & $\begin{array}{l}\text { Plant } \\
\text { height } \\
\text { (cm) }\end{array}$ & $\begin{array}{l}\text { No. of } \\
\text { shoots } \\
\text { plant }^{-1}\end{array}$ & $\begin{array}{l}\text { No. of } \\
\text { leaves } \\
\text { plant }{ }^{-1}\end{array}$ & $\begin{array}{l}\text { Leaf area } \\
\left(\mathrm{cm}^{2}\right)\end{array}$ & LAI & $\begin{array}{c}\text { LAD } \\
\text { (days) }\end{array}$ & $\begin{array}{c}\text { TDM } \\
\left(\text { g plant }^{-1}\right)\end{array}$ \\
\hline \multicolumn{8}{|c|}{ Fertilizer level (F) } \\
\hline$F_{1}$ & 65.0 & 3.2 & 63.6 & 5155 & 4.3 & 72.1 & 46.4 \\
\hline$F_{2}$ & 68.1 & 3.4 & 70.7 & 6159 & 5.1 & 84.3 & 54.2 \\
\hline S.Em.土 & 0.56 & 0.11 & 1.33 & 112 & 0.09 & 1.20 & 0.48 \\
\hline CD@ $9 \%$ & 1.63 & NS & 3.91 & 330 & 0.27 & 3.53 & 1.40 \\
\hline \multicolumn{8}{|c|}{ Compost level (C) } \\
\hline $\mathrm{C}_{0}$ & 60.7 & 2.8 & 56.0 & 3619 & 3.0 & 53.8 & 34.0 \\
\hline $\mathrm{C}_{1}$ & 68.3 & 3.4 & 69.3 & 6407 & 5.3 & 86.8 & 53.2 \\
\hline $\mathrm{C}_{2}$ & 70.6 & 3.8 & 76.2 & 6945 & 5.7 & 93.9 & 63.6 \\
\hline S.Em. \pm & 0.68 & 0.13 & 1.63 & 137 & 0.11 & 1.47 & 0.59 \\
\hline CD@ 5\% & 2.00 & 0.377 & 4.78 & 404 & 0.33 & 4.32 & 1.72 \\
\hline \multicolumn{8}{|c|}{ Green manures (G) } \\
\hline $\mathrm{G}_{1}$ & 65.1 & 3.2 & 64.6 & 5102 & 4.2 & 72.0 & 46.1 \\
\hline $\mathbf{G}_{2}$ & 68.0 & 3.5 & 69.7 & 6212 & 5.1 & 84.4 & 54.5 \\
\hline S.Em.土 & 0.56 & 0.11 & 1.33 & 112 & 0.09 & 1.20 & 0.48 \\
\hline CD @ 5\% & 1.63 & NS & 3.91 & 330 & 0.27 & 3.53 & 1.40 \\
\hline \multicolumn{8}{|c|}{ Interaction $(\mathrm{F} \times \mathrm{C} \times \mathrm{G})$} \\
\hline $\mathrm{F}_{1} \times \mathrm{C}_{0} \times \mathrm{G}_{1}$ & 56.1 & 2.7 & 50.6 & 2679 & 2.2 & 39.5 & 26.0 \\
\hline $\mathrm{F}_{1} \times \mathrm{C}_{0} \times \mathrm{G}_{2}$ & 59.9 & 2.9 & 53.6 & 3316 & 2.7 & 48.2 & 31.6 \\
\hline $\mathrm{F}_{1} \times \mathrm{C}_{1} \times \mathrm{G}_{1}$ & 66.4 & 3.1 & 63.3 & 4827 & 4.0 & 72.0 & 45.0 \\
\hline$F_{1} \times C_{1} \times G_{2}$ & 69.8 & 3.6 & 73.6 & 7332 & 6.1 & 97.4 & 60.8 \\
\hline$F_{1} \times C_{2} \times G_{1}$ & 66.8 & 3.3 & 65.6 & 5411 & 4.5 & 76.8 & 49.4 \\
\hline $\mathrm{F}_{1} \times \mathrm{C}_{2} \times \mathrm{G}_{2}$ & 71.0 & 3.8 & 75.0 & 7367 & 6.1 & 98.6 & 65.3 \\
\hline $\mathrm{F}_{2} \times \mathrm{C}_{0} \times \mathrm{G}_{1}$ & 61.4 & 2.9 & 57.6 & 3951 & 3.2 & 59.5 & 37.2 \\
\hline $\mathrm{F}_{2} \times \mathrm{C}_{0} \times \mathrm{G}_{2}$ & 65.5 & 2.9 & 62.0 & 4531 & 3.7 & 68.1 & 41.3 \\
\hline $\mathrm{F}_{2} \times \mathrm{C}_{1} \times \mathrm{G}_{1}$ & 68.2 & 3.4 & 69.6 & 6317 & 5.2 & 85.1 & 50.8 \\
\hline $\mathrm{F}_{2} \times \mathrm{C}_{1} \times \mathrm{G}_{2}$ & 68.8 & 3.5 & 70.6 & 7152 & 5.9 & 92.9 & 56.2 \\
\hline $\mathrm{F}_{2} \times \mathrm{C}_{2} \times \mathrm{G}_{1}$ & 71.7 & 3.9 & 81.0 & 7425 & 6.1 & 99.0 & 68.1 \\
\hline $\mathrm{F}_{2} \times \mathrm{C}_{2} \times \mathrm{G}_{2}$ & 73.1 & 4.1 & 83.3 & 7576 & 6.3 & 101.3 & 71.5 \\
\hline S.Em. \pm & 1.36 & 0.26 & 3.27 & 275 & 0.23 & 2.95 & 1.17 \\
\hline CD@ $9 \%$ & NS & NS & NS & NS & NS & NS & 3.44 \\
\hline
\end{tabular}

$\mathrm{F}_{1}-75 \%$ RDF; $\mathrm{F}_{2}-100 \%$ RDF; $\mathrm{C}_{0}$ - Control; $\mathrm{C}_{1}-12.5 \mathrm{t} \mathrm{ha}^{-1}$ compost; $\mathrm{C}_{2}-25 \mathrm{t} \mathrm{ha}^{-1}$ compost $\mathrm{G}_{1}-$ in-situ green manuring with sunhemp; $\mathrm{G}_{2}-$ in-situ green manuring with cowpea NS - Non significant 
Table.4 Economics of in potato as influenced by INM practices with in-situ green manuring

\begin{tabular}{|l|c|c|c|c|c|}
\hline Treatments & $\begin{array}{c}\text { Tuber } \\
\text { yield } \\
\left(\mathrm{t} \mathrm{ha}^{-1}\right)\end{array}$ & $\begin{array}{c}\text { Cost of } \\
\text { cultivation } \\
\left(\text { Rs. ha }^{-1}\right)\end{array}$ & $\begin{array}{c}\text { Gross returns } \\
(\text { Rs. ha }\end{array}$ & $\begin{array}{c}\text { Net returns } \\
\left(\text { Rs. ha }^{-1}\right)\end{array}$ & B: C \\
\hline $\mathrm{T}_{1}-\mathrm{F}_{1} \times \mathrm{C}_{0} \times \mathrm{G}_{1}$ & 10.67 & 57500 & 106700 & 49200 & 1.85 \\
\hline $\mathrm{T}_{2}-\mathrm{F}_{1} \times \mathrm{C}_{0} \times \mathrm{G}_{2}$ & 11.16 & 57500 & 111600 & 54100 & 1.94 \\
\hline $\mathrm{T}_{3}-\mathrm{F}_{1} \times \mathrm{C}_{1} \times \mathrm{G}_{1}$ & 11.87 & 64250 & 118700 & 54450 & 1.84 \\
\hline $\mathrm{T}_{4}-\mathrm{F}_{1} \times \mathrm{C}_{1} \times \mathrm{G}_{2}$ & 16.58 & 64250 & 165800 & 101550 & 2.58 \\
\hline $\mathrm{T}_{5}-\mathrm{F}_{1} \times \mathrm{C}_{2} \times \mathrm{G}_{1}$ & 13.23 & 71000 & 132300 & 61300 & 1.86 \\
\hline $\mathrm{T}_{6}-\mathrm{F}_{1} \times \mathrm{C}_{2} \times \mathrm{G}_{2}$ & 16.80 & 71000 & 168000 & 97000 & 2.36 \\
\hline $\mathrm{T}_{7}-\mathrm{F}_{2} \times \mathrm{C}_{0} \times \mathrm{G}_{1}$ & 11.65 & 62000 & 116500 & 54500 & 1.87 \\
\hline $\mathrm{T}_{8}-\mathrm{F}_{2} \times \mathrm{C}_{0} \times \mathrm{G}_{2}$ & 11.72 & 62000 & 117200 & 55200 & 1.89 \\
\hline $\mathrm{T}_{9}-\mathrm{F}_{2} \times \mathrm{C}_{1} \times \mathrm{G}_{1}$ & 13.53 & 68750 & 135300 & 66550 & 1.96 \\
\hline $\mathrm{T}_{10}-\mathrm{F}_{2} \times \mathrm{C}_{1} \times \mathrm{G}_{2}$ & 15.06 & 68750 & 150600 & 81850 & 2.19 \\
\hline $\mathrm{T}_{11}-\mathrm{F}_{2} \times \mathrm{C}_{2} \times \mathrm{G}_{1}$ & 16.93 & 72500 & 169300 & 96800 & 2.33 \\
\hline $\mathrm{T}_{12}-\mathrm{F}_{2} \times \mathrm{C}_{2} \times \mathrm{G}_{2}$ & 17.26 & 72500 & 172600 & 100100 & 2.38 \\
\hline
\end{tabular}

$\mathrm{F}_{1}-75 \%$ RDF; $\mathrm{F}_{2}-100 \%$ RDF; $\mathrm{C}_{0}-$ Control; $\mathrm{C}_{1}-12.5 \mathrm{tha}^{-1}$ compost; $\mathrm{C}_{2}-25 \mathrm{t} \mathrm{ha}^{-1}$ compost

$\mathrm{G}_{1}-$ in-situ green manuring with sunhemp; $\mathrm{G}_{2}$ - in-situ green manuring with cowpea

Similarly in-situ green manuring with cowpea recorded significantly higher plant height $(68.0 \mathrm{~cm})$, number of leaves $\left(69.7\right.$ plant $\left.^{-1}\right)$, leaf area $\left(6212 \mathrm{~cm}^{2}\right.$ plant $\left.^{-1}\right)$, leaf area index (5.1), leaf area duration (84.4 days) and total dry matter production (54.5 $\mathrm{g} \mathrm{plant}^{-1}$ ) except number of shoots plant ${ }^{-1}$ compare to in-situ green manuring with sunhemp.

These findings are in accordance with the results obtained by several researchers (Plotkin, 2000 and Christopher, 2014) who found that growth of potato after green manure crops were higher.

The interaction effect between fertilizer levels, compost levels and in-situ green manuring found to be non-significant.

\section{Economics (Table 4)}

The higher net returns and $\mathrm{B}: \mathrm{C}$ ratio (Rs. $1,01,550 \mathrm{ha}^{-1}$ and 2.58, respectively) was recorded in the treatment with $75 \%$ $\mathrm{RDF}+12.5 \mathrm{t} \mathrm{ha}^{-1}$ compost + in-situ green manuring with cowpea $\left(\mathrm{T}_{4}\right)$ followed by
$100 \% \mathrm{RDF}+25 \mathrm{t} \mathrm{ha}^{-1}$ compost + in-situ green manuring with cowpea $\left(\mathrm{T}_{12}\right)$. The lower $\mathrm{B}$ : $\mathrm{C}$ ratio (1.84) was noticed in the treatment with $75 \% \mathrm{RDF}+12.5 \mathrm{t} \mathrm{ha}^{-1}$ compost + in-situ green manuring with sunhemp $\left(\mathrm{T}_{3}\right)$. This was mainly due to higher cost of cultivation accounted by additional price of fertilizer and compost.

Potato responds significantly to fertilizer, compost and green manure levels. Our results indicated that growth parameters of potato were significantly increased as fertilizer levels and compost levels increased also with in-situ green manuring of cowpea.

Increase in the dry matter production of potato in case of in-situ green manuring with cowpea was 18.2 per cent compared to sunhemp. Application $75 \%$ recommended dose of NPK with $12.5 \mathrm{t} \mathrm{ha}^{-1}$ compost and insitu green manuring with cowpea recorded less reduction in the tuber yield with high net returns and $\mathrm{B}: \mathrm{C}$ ratio and it is economically feasible for the potato cultivation by saving $25 \%$ fertilizer and $50 \%$ compost. 


\section{Acknowledgement}

The authors are thankful to the Dean and farm superintendent, College of Agriculture, Hassan, UAS, Bangalore for providing research facilities to carry out this experiment.

\section{References}

Ashwini Kumar Sharma, and Sarjeet Singh. 2000. Effect of farm yard manure, green manure and fertilizer levels on seed potato production in north-western hills. Potato J., 32(2): 133-144.

Brian, F.F., 2001. The value of green manures in potato cropping systems. In: University of Idaho conference. pp. 127-130.

Christopher, M.T., 2014. Effect of green manure and intercropping on potato production in the western highlands of Cameroon. Int. J. Scientific Technol. Res., 3(9): 204-208.

Gomez, K.A., and Gomez, A.A., 1984. In: Statistical Procedures for Agricultural Research. Second Edn. John Wiley and sons, New York.pp.68.

Krishnamurthy, N., Abdul Khalak, G.M., Sujith, H.K., Basavaraj, Prasanna, K.P.R. and Shivaraj, B., 2002. Integrated nutrient supply and management for potato production in alfisols. Potato-global res. dev., 2: 852856.

Meelu, O.P., Singh, Y. and Singh, B., 2007. Green manuring for soil productivity improvement. Food and Agricultural Organization of the United Nations. Daya Publishing house, New Delhi, 133p.

Mondal, S.S., Debabrata Acharya, Arup Ghosh and Bug, A., 2005. Integrated nutrient management on the growth, productivity and quality of potato in Indo-gangetic plains of west Bengal. Potato J., 32(1-2): 75-78.

Plotkin, J.M.B., 2000. The Effects of Green Manure Rotation Crops on Soils and Potato Yield and Quality. Master's Thesis, University of Maine, Dept. of Plant, Soil and Environmental Science, Orono, USA. pp.117.

Riley, H., 2000. Level and timing of nitrogen fertilizer application to early and semiearly potatoes (Solanum tuberosum L.) grown with irrigation on light soils in Norway. Acta agricultura Scandinavica. Section B, Soil and plant science, 50: 122-134.

Van Delden, A., 2001. Yield and growth components of potato and wheat under organic nitrogen management. Agron. J. 93: $1370-1385$.

\section{How to cite this article:}

Prabhudeva, D.S., R. Jayaramaiah and Thimmegowda, M.N. 2018. Inclusion of in-situ Green Manuring as One of the Important INM Practice to Improve the Growth and Economics of Potato (Solanum tuberosum L.). Int.J.Curr.Microbiol.App.Sci. 7(11): 692-698. doi: https://doi.org/10.20546/ijcmas.2018.711.082 